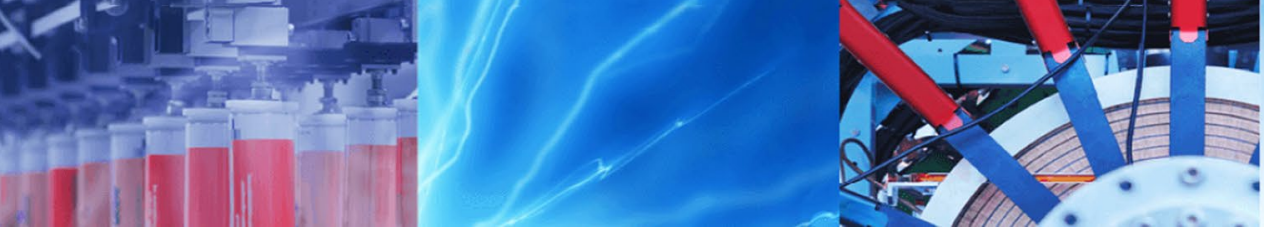

Research Article

\title{
Evaluating the electrical resistivity of microbial-induced calcite precipitate-treated lateritic soil
}

\author{
J. E. Sani ${ }^{1} \cdot$ G. Moses $^{1}$ · F. O. P. Oriola ${ }^{1}$
}

Received: 11 May 2020 / Accepted: 29 July 2020 / Published online: 10 August 2020

(c) Springer Nature Switzerland AG 2020

\begin{abstract}
Organisms or chemicals introduced into soils for soil improvement tend to make such soil reactive and this may affect the parameters that are used to determine the engineering and other properties of the soil. In this study, the electrical resistivity of Bacillus pumilus microbial-induced calcite precipitate-treated lateritic soil at different compactive effort was evaluated; lateritic soil was treated with stepped densities of $B$. pumilus suspensions of $0 / \mathrm{ml}, 1.5 \times 10^{8} / \mathrm{ml}, 6.0 \times 10^{8} / \mathrm{ml}$, $12 \times 10^{8} / \mathrm{ml}, 18 \times 10^{8} / \mathrm{ml}$ and $24 \times 10^{8} / \mathrm{ml}$, respectively, and compacted with three compaction energies, namely British Standard Light (BSL), West African Standard (WAS) and British Standard Heavy. The treated soil samples were cured for 7 , 28 and 56 days to also see the effect of the curing period on the resistivity of the treated lateritic soil. The resistivity test result shows an increase in resistivity value with an increase in B. pumilus suspension density and also with an increase in compactive energy. Though there is a marginal increase between BSL and WAS compactive effort. The peak resistivity value was obtained at $2.4 \times 10^{9} \mathrm{cells} / \mathrm{ml}$ of $B$. pumilus suspension density for all compactive effort considered. The effect of curing days indicates that beyond 28 days there is only a marginal increase in resistivity value because there is little or no increase in the resistivity values obtained.
\end{abstract}

Keywords Bacillus pumilus · Electrical resistivity · Compactive effort · Curing days · Lateritic soil

\section{Introduction}

Electrical resistivity of soil is a measure of the resistance that a soil type (of a specified volume) offers to the flow of electricity through it. An estimate of soil resistivity and its variation with depth in the soil is critical in the designing of the grounding system in an electrical substation. It is also needed for designing earthen electrodes for highvoltage direct current transmission systems. The soil resistivity value varies substantially with changes in moisture content, chemical content (salts), temperature, etc. [43]. It is measured in Ohm-meter (Om).

The geotechnical community often assumes that natural soil deposits and graded fills are inert due to their ignoring biological presence in soils (that soils are free of organisms) and in a stable state. However, biological presence can modify the engineering properties of soil greatly [9]. Bio-geochemical processes have been used to improve the engineering properties of soil such as physical properties, conduction properties, mechanical properties and chemical composition and are well documented in the literature $[8,9,14,19,20,38,40,42]$. Therefore, it becomes necessary to determine the effect of biological processes on properties of treated soils, most especially those that have found popular use in construction, such as laterite.

Laboratory methods including studies of the injection method, injection volume, influence of the calcium source, concentration of cementation reagent, and factors that affect the MICP process have been investigated with the aim of using the findings for various engineering applications to be carried out in the field [32]. Commonly found soil bacteria (S. pasteurii, Bacillus coagulans

J. E. Sani, jesani@nda.edu.ng | ${ }^{1}$ Department of Civil Engineering, Nigerian Defence Academy, Kaduna, Nigeria.

SN Applied Sciences (2020) 2:1492 | https://doi.org/10.1007/s42452-020-03285-x 
and Bacillus pumilus) were cultured from a tropical residual soil (lateritic soil) which met the geometric compatibility requirements for this research technique, obtaining positive results [29-31].

Laterites, which are formed in tropical and sub-tropical regions of hot and humid climatic conditions with heavy rainfall, warm temperature and good drainage according to Townsend [39], are very rich in iron and aluminium and occur mostly as the capping of the hill. They, therefore, find extensive use in numerous construction activities such as subgrade material for road construction and brick production material [12]. Similarly, they are categorized as natural resources of importance in geoenvironmental applications [10] because of their adequate chemical resistance and low desiccation-induced shrinkage potential [25]. Most tropical laterites are predominantly composed of kaolinite, non-swelling, non-expanding 1:1 clay minerals which are engineering materials [23]; some often contain swelling 2:1 clay mineral sand and, therefore, constitute problematic engineering structures.

Great success has been recorded in strength and durability of an MICP-treated soil, but little work has been done to determine the electrical resistivity of an MICP-treated soil. The aim of this study is to evaluate the electrical resistivity of B. pumilus microbial-induced calcite precipitatetreated lateritic soil at different compactive effort. Microbial-induced calcite precipitate (MICP) is a technology by which microorganisms are used to improve the geotechnical properties of soils, by the production of calcite that binds the soil particle as a result of the introduction of bacteria (B. pumilus) and cementation reagents into the soil [7, $15,27]$. Successes in this research can be upscale to field applications of the MICP technique to improve the electrical resistivity of soil. van Paassen [41] carried out the first full-scale field application of the MICP technique, producing very promising findings. Despite the promising finding of field applications, the lack of understanding of the long-term mechanical properties of bio-cemented soil has delayed its extensive acceptance for practical engineering applications $[11,18]$. This research considered curing the MICP-treated soil for 56 days to see the sustainability of the resistivity value.

\section{Materials and methods}

\subsection{Soil}

The lateritic soil sample used in this study was collected by the method of disturbed sampling from Abagana (Lat 6.186549 ${ }^{\circ}$ and Long. 6.980070 ${ }^{\circ}$, Njikoka Local Government Area of Anambra state, South East Nigeria. The soil samples were collected at a depth of $1.5 \mathrm{~m}$ below the natural earth surface to minimize organic matter.

\subsection{Microorganisms}

Bacillus pumilus which was identified by the Microgen ID was used in this study. The B. pumilus was used for this study because it was identified from the lateritic soil used and it will enhance bio-stimulation which is obtaining bacteria from the soil, culture it in mass and reintroduce it into the soil for MICP process. The bacteria were cultured in liquid media consisting of $3 \mathrm{~g}$ Nutrient Broth, $330 \mathrm{mM}$ of urea, $186.7 \mathrm{mM}$ of $\mathrm{NH}_{4} \mathrm{Cl}$, and $25.3 \mathrm{mM}$ of $\mathrm{NaHCO}_{3}$ per litre of glass distilled water, with a $\mathrm{pH}$ measured at 9.7. Liquid media were sterilized by autoclaving for $20 \mathrm{~min}$ at $121^{\circ} \mathrm{C}$. The bacterial cell densities were determined using McFarland Turbidity scale using $0,0.5,2,4,6$ and 8 being equivalent to $1.5 \times 10^{8} \mathrm{cells} / \mathrm{ml}, 6.0 \times 10^{8} \mathrm{cell} / \mathrm{ml}, 12 \times 10^{8} \mathrm{cell} / \mathrm{s} / \mathrm{ml}$, $18 \times 10^{8} \mathrm{cell} / \mathrm{s} / \mathrm{ml}$ and $24 \times 10^{8} \mathrm{cells} / \mathrm{ml}$, respectively [17]. The growth phase of the inoculating culture was controlled. The $B$. pumilus suspensions were prepared in stepped suspension densities of 0 cells $/ \mathrm{ml}$ (which is the control), $1.5 \times 10^{8}$ cells $/ \mathrm{ml}, 6.0 \times 10^{8}$ cells $/ \mathrm{ml}, 12.0 \times 10^{8}$ cells $/ \mathrm{ml}$, $18.0 \times 10^{8}$ cells $/ \mathrm{ml}$ and $24.0 \times 10^{8}$ cells $/ \mathrm{ml}$, respectively, for the MICP treatment and was used in treating each soil sample.

\subsection{Cementation reagents}

Cementation reagents served as the raw materials for calcite formation in the MICP process. The cementation reagents that were employed in this study comprise $333 \mathrm{mM}$ of urea $\left(\mathrm{CO}\left(\mathrm{NH}_{2}\right)_{2}\right)$ and $25.2 \mathrm{mM}$ of calcium chloride $\left(\mathrm{CaCl}_{2}\right)$. The cementation reagents also contained $3 \mathrm{~g}$ nutrient broth, $186.7 \mathrm{mM}$ ammonium chloride $\left(\mathrm{NH}_{4} \mathrm{Cl}\right)$, and $25.3 \mathrm{mM}$ of sodium bicarbonate $\left(\mathrm{NaHCO}_{3}\right)$ per litre of deionized water which is an alkaline culture medium $[7,34,36,37]$.

\subsection{Compaction}

Each soil sample was compacted in the compaction mould using British Standard Light (BSL) or Standard Proctor (SP), West African Standard (WAS) and British Standard heavy (BSH) compaction energies in accordance with BS 1377 [5] to determine the compaction characteristics (Optimum Moisture Content (OMC)) and Maximum Dry Density (MDC)) of the natural soil. Soil samples were passed through $4.76 \mathrm{~mm}$ sieve. Soil samples were mixed with $B$. pumilus suspension density at $25 \%$ of the natural OMC of all compactive effort used while the remaining $75 \%$ was for the cementation reagent. Soil samples were allowed to air dry on trays and afterwards tests were carried out on 
them. Tests to determine the moisture-density relationships were carried out in accordance with BS 1377 [5] for the three energies considered.

\subsection{MICP treatment}

After compaction, the samples in the compaction mould were saturated under gravity with the various B. pumilus suspension densities. Each specimen was left for $3 \mathrm{~h}$ to ensure that the pores within the soil matrix are filled with the bacteria suspension before the introduction of the cementitious reagent also by gravity into the pores of the soil matrix until they were completely saturated. Saturation was ascertained by the cementitious reagent dripping from the bottom of the compaction mould and the applied reagent on the surface of the sample does not permeate into the soil anymore. A series of compacted soil samples were repeatedly treated (one each) with different bacterial suspension densities (control; $1.5 \times 10^{8}$ cells per $\mathrm{ml}$; etc.) every $6 \mathrm{~h}$ for 2 days and the cementitious reagent with alkaline culture medium was injected into the soil to initiate the MICP process. Upon completion of the treatment, the soil specimen was used for the electrical resistivity test. Three samples were tested for each suspension density, and the average value was taken as the electrical resistivity of the soil.

\subsection{Index properties}

The index properties of the soil were determined in accordance with specifications outlined in BS. 1377 [5]. Soil passing through British Standard No. 40 sieve $(425 \mu \mathrm{m}$ aperture) was used to determine Atterberg limits consisting of liquid limit, plastic limit, and plasticity index, and the linear shrinkage was also determined. The various $B$. pumilus suspension densities were mixed at $25 \%$ of the natural liquid limit value while the cementation reagent was mixed at $75 \%$ of the same natural liquid limit value. The treated soil specimens were then air-dried at the laboratory temperature of $23 \pm 2{ }^{\circ} \mathrm{C}$, before being used to carry out the test. The soil samples were treated in stepped densities of $B$. pumilus cells $/ \mathrm{ml}$ considered. Three samples were tested for each suspension density, and the average value was taken.

\subsection{Specific gravity}

Dried treated samples mixed for index properties were used for the test in accordance with specification outlined in BS. 1377 [5].

\subsection{Calcite content determination}

The calcite content was estimated using the acid washing method as described by Burbank et al. [4] and Choi et al. [6]. Moreover, $5 \mathrm{~g}$ of the treated sample used in volumetric shrinkage strain test was cut from surface to core of the specimen and weighed (denoted as $W_{1}$ ) and placed in a $50 \mathrm{ml}$ beaker; $20 \mathrm{ml}$ of $2 \mathrm{M}$ of hydrochloric acid (HCL) was added into a beaker and stirred with a glass rod until the calcium carbonate was dissolved in the acid; it was then transferred to Whatman filter paper and washed with distilled water for $10 \mathrm{~min}$. The filtrate was oven-dried at $35^{\circ} \mathrm{C} / 105^{\circ} \mathrm{C}$. The dried weight $\left(W_{2}\right)$ was recorded. The calcite content was computed as follows:

$W_{\mathrm{D}}(\mathrm{g})=W_{1}-W_{2}$

where $W_{D}$ is the weight of the calcite content (CC), $W_{1}$ is the weight of the sample before acid washing, and $W_{2}$ is the weight of the sample after acid washing

Or

$\mathrm{CC}(\%)=100-\frac{W_{2}}{W_{1}} \times 100$

\subsection{Electrical resistivity measurement}

The electrical resistivity of the soil is determined by measuring the resistance between two points in the soil, and this is done by measuring the voltage across a pair of electrodes by transmitting a controlled DC or AC current (I) between two electrodes pushed into the ground while measuring the potential $(V$ ) between two other electrodes. The setup for the measurement of electrical resistivity is shown in Fig. 1 and the Schematic of M.C. Miller Soil Box utilized is shown in Fig. 2. The resistivity of the samples was measured after the samples were cured for 7 days, 28 days and 56 days to also see the effect of long-time

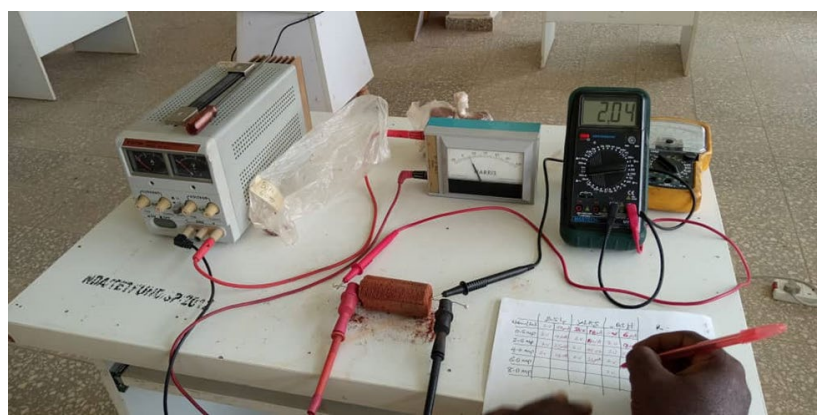

Fig. 1 Soil resistivity testing system utilized in this research 


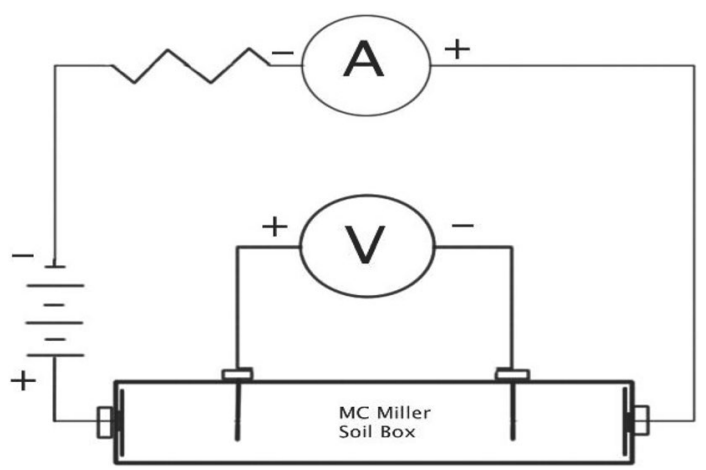

Fig. 2 Schematic of M.C. Miller Soil Box

curing on the resistivity value of $B$. pumilus treated soil at the stepped suspension density considered.

The resistance $(R)$ is calculated using Ohm's Law as given in Eq. (3).

$R=\frac{V}{l}$

where $V$ is the voltage ( $V$ ) and $/$ is the current (amp).

For the case of a pair of electrodes in homogeneous, isotropic conducting media, the relationship between resistance and resistivity is linear and the material resistivity $(\rho)$ can then be defined as in the following Eq. (4):

$\rho=R A / I$

where $I$ is the length $(\mathrm{m})$ between electrodes and $R$ is the resistance $(\Omega)$.

In the actual field measurement of electrical resistivity, there are many different kinds of electrode arrays or configuration that one could adopt. Some of the typical electrode arrays are Wenner, Schlumberger, dipole-dipole and pole-pole. In this research, however, the disc electrode method in accordance with BS 1377 was adopted to enable undisturbed or disturbed samples of soil to be measured in the laboratory. By using this disc electrode method of measurement, the resistivity of the soil $(\rho)$ in $\Omega . m$ is determined by the formula given in Eq. (5).

$\rho=\left(\frac{A}{l}\right) R$

where $A$ is the cross-sectional area $\left(\mathrm{m}^{2}\right)$ of the sample, $I$ is the length $(\mathrm{m})$ and $R$ is the resistance $(\Omega)$.

The technical requirement of electrical resistivity is that it has a relationship with the soil type, degree of compaction and soil moisture content. Electrical resistivity increases with the degree of compaction (compaction energies). Electrical resistivity can be considered as a quick and clean quality control tool for field compaction. For
Table 1 Oxide composition of lateritic soil

\begin{tabular}{ll}
\hline Oxide & Concentration \% \\
\hline $\mathrm{SiO}_{2}$ & 56.5 \\
$\mathrm{Al}_{2} \mathrm{O}_{3}$ & 19.00 \\
$\mathrm{CaO}$ & 0.33 \\
$\mathrm{TiO}_{2}$ & 2.89 \\
$\mathrm{~V}_{2} \mathrm{O}_{5}$ & 0.061 \\
$\mathrm{Cr}_{2} \mathrm{O}_{3}$ & 0.051 \\
$\mathrm{Fe}_{2} \mathrm{O}_{3}$ & 15.41 \\
$\mathrm{MnO}$ & 0.075 \\
$\mathrm{CuO}$ & 0.056 \\
$\mathrm{ZrO}$ & 0.290 \\
$\mathrm{L.O} . \mathrm{I}$ & 4.54 \\
\hline
\end{tabular}

After Osinubi et al. [28]

each site, laboratory tests could be carried out to determine the site-specific relation between the electrical resistivity and the degree of compaction and water content [22].

\section{Results and discussion}

\subsection{Oxide composition of lateritic soil}

The results of X-Ray Fluorescence (XRF) carried out in the Nigeria Geological Survey Laboratory Kaduna, Kaduna State to determine the oxide composition of lateritic soil is shown in Table 1.

The silica-sesquioxide ratio of 1.65 , which is between 1.33 and 2.00 classifies the natural material as lateritic soil in accordance with the specifications given by Joachin and Kandiah [16].

\subsection{Specific gravity}

The variation of the specific gravity of lateritic soil with $B$. pumilus is shown in Fig. 3. The specific gravity of the soil generally decreased with increased $B$. pumilus suspension density. Its value decreased from 2.86 for the natural lateritic soil to 2.63 at $1.8 \times 10^{9} \mathrm{cells} / \mathrm{ml}$ and thereafter increased to 2.68 at $2.4 \times 10^{9} \mathrm{cells} / \mathrm{ml}$. This decrease may be caused by the calcites formed during the MICP process which caused the soil particles to be flocculated within the soil matrix and hence loosely parked particles. This result is similar to findings by Osinubi et al. [24, 26].

\subsection{Index properties}

The index properties of the lateritic soil and treated lateritic soil are summarized in Table 2 . The natural soil is reddish-brown in colour and had $35.3 \%$ passing through 


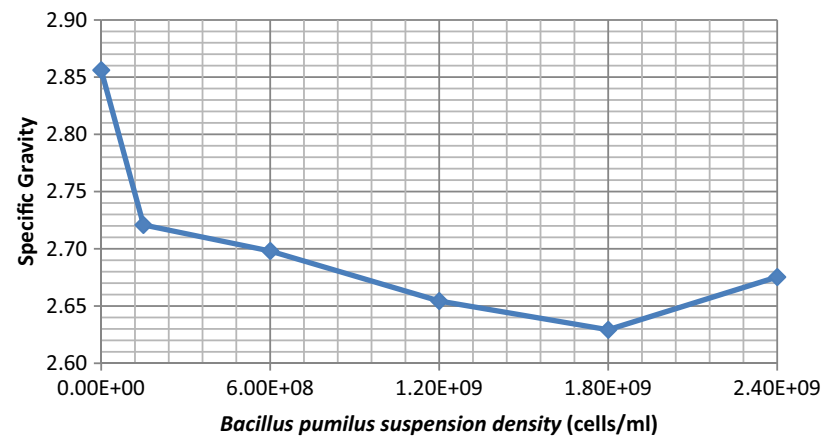

Fig. 3 Variation of the specific gravity of lateritic soil with B. pumilus suspension treatment

BS sieve no. 200. It was classified as clayey sand (SC) under the USCS [3] and A-4(0) under the AASHTO system [1] with the dominant clay mineral being kaolinite.

The variation of Atterberg limits [liquid limit (LL), plastic limit (PL), plasticity index (PI)] and linear shrinkage (LS) of the lateritic soil treated with cementitious reagent at various suspension densities of $B$. pumilus is shown in Fig. 4. It was observed that there was a decrease in the liquid limit values from 36 to $34 \%$ at $1.2 \times 10^{9}$ cells/ $\mathrm{ml}$ of $B$. pumilus suspension density and thereafter it increased to 35.5 at $2.4 \times 10^{9}$ cells $/ \mathrm{ml}$ of $B$. pumilus suspension density. A plasticity index value of $14.02 \%$ was recorded for the natural soil which dropped to a value of $9.17 \%$ at $1.2 \times 10^{9}$ cells $/ \mathrm{ml}$ of $B$. pumilus suspension density and thereafter increased to a value of $12.66 \%$ at $2.4 \times 10^{9}$ cells $/ \mathrm{ml}$ of $B$. pumilus suspension density. The linear shrinkage decreased from $8.82 \%$ for the natural soil to $7.27 \%$ at $1.2 \times 10^{9}$ cells $/ \mathrm{ml}$ of $B$. Pumilus suspension density and thereafter slightly increased to $7.86 \%$ at $2.4 \times 10^{9}$ cells $/ \mathrm{ml}$ of $B$. pumilus suspension density.

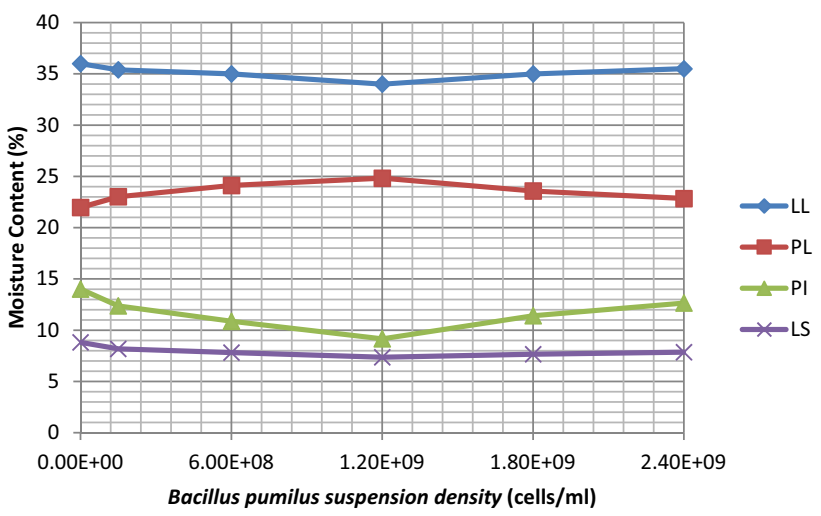

Fig. 4 Variation of the Atterberg limits of lateritic soil at various $B$. pumilus suspension density treatments

This result is contrary to the reports by Osinubi et al. [24] where it was reported that the liquid limit value rose with an increase in B. pumilus treatment. However, similar studies [33, 35], which used cement to stabilize lateritic soil reported the effects of $\mathrm{Ca}^{2+}$ on the liquid limit of the clay soil, showed a decrease in the liquid limit value. The Atterberg test result may not be unconnected with the flocculation and agglomeration of the clay particles which occurred as a result of the production of calcites in the MICP process. This result is similar to findings by Osinubi et al. $[24,26]$ where it was reported that the plastic limit value rose with an increase in $B$. pumilus suspension density treatment on lateritic soil.

\subsection{Compaction characteristics}

\subsubsection{Maximum dry density}

The variation of the maximum dry density (MDD) of MICP-treated soil with B. pumilus suspension density for
Table 2 Properties of the natural and treated lateritic soil

\begin{tabular}{|c|c|c|c|c|c|c|}
\hline \multirow[t]{2}{*}{ Property } & \multicolumn{6}{|c|}{ B. pumilus (suspension density/ml) } \\
\hline & 0 & $1.5 \mathrm{E} 8 / \mathrm{ml}$ & $6.0 \mathrm{E} 8 / \mathrm{ml}$ & $12.0 \mathrm{E} 8 / \mathrm{ml}$ & $18.0 \mathrm{E} 8 / \mathrm{ml}$ & $24.0 \mathrm{E} 8 / \mathrm{m}$ \\
\hline Natural moisture content (\%) & 11.8 & & & & & \\
\hline $\begin{array}{l}\text { Percentage passing no. } 200 \\
\text { sieve (wet sieving) }\end{array}$ & 35.3 & & & & & \\
\hline Liquid limit (\%) & 36 & 35.4 & 35 & 34 & 35 & 35.5 \\
\hline Plastic limit (\%) & 21.98 & 23.02 & 24.12 & 24.83 & 23.58 & 22.84 \\
\hline Plasticity index (\%) & 14.02 & 12.38 & 10.88 & 9.17 & 11.42 & 12.66 \\
\hline Linear shrinkage (\%) & 8.82 & 8.19 & 7.82 & 7.37 & 7.66 & 7.86 \\
\hline Specific gravity & 2.86 & 2.72 & 2.70 & 2.65 & 2.63 & 2.68 \\
\hline AASHTO classification & $A-4(0)$ & $A-4(0)$ & $A-4(0)$ & $A-4(0)$ & $A-4(0)$ & $A-4(0)$ \\
\hline USCS & SC & SC & SC & SC & SC & SC \\
\hline Colour & Reddish brown & & & & & \\
\hline Dominant clay mineral & Kaolinite & & & & & \\
\hline
\end{tabular}


the three compactive effort is shown in Fig. 5. The MDD decreased with increasing $B$. pumilus suspension density for all compactive energies considered after an initial increase to $2 \mathrm{Mg} / \mathrm{m}^{3}$ at $1.5 \times 10^{8}$ cells $/ \mathrm{ml}$ of $B$. pumilus suspension density for BSL and increase to $2 \mathrm{Mg} / \mathrm{m}^{3}$ and $2.05 \mathrm{Mg} / \mathrm{m}^{3}$ at $6.0 \times 10^{8}$ cells $/ \mathrm{ml}$ of $B$. pumilus suspension density each for WAS and BSH, respectively. The MDD decreased to $1.87 \mathrm{Mg} / \mathrm{m}^{3}, 1.86 \mathrm{Mg} / \mathrm{m}^{3}$ and $1.98 \mathrm{Mg} / \mathrm{m}^{3}$ for samples compacted at BSL, WAS and $\mathrm{BSH}$, respectively, when treated with up to $2.4 \times 10^{9}$ cells $/ \mathrm{ml}$ of $B$. pumilus suspension density. The reduction in MDD is probably due to the lower specific gravity values as the B. pumilus suspension density increased. A similar trend was also reported by Abo-El-Enein et al. [2] and Osinubi et al. [24, 26].

\subsubsection{Optimum moisture content}

The variation of optimum moisture content (OMC) with $B$. pumilus cells $/ \mathrm{ml}$ at different compactive effort considered is shown in Fig. 6.

The OMC generally increased with increased B. pumilus suspension density treatment after an initial drop in the OMC value at $1.5 \times 10^{8}$ cells $/ \mathrm{ml}$ for both $\mathrm{BSL}$ and $\mathrm{BSH}$ compaction. The OMC increased to $14 \%$ and $13.2 \%$ at $2.4 \times 10^{9}$ cells $/ \mathrm{ml}$ for both BSL and WAS compacted samples while the BSH compaction increases to $12 \%$ at $1.2 \times 10^{9}$ cells $/ \mathrm{ml}$ and thereafter decreases. The increase in OMC recorded for all effort considered could be caused by the urease enzyme produced by $B$. pumilus that reacted with the cementation reagent to form larger surface areas that had a greater affinity for water thereby leading to higher moisture content. This can also be attributed to the quantity of calcite that bridged the soil particles together by clogging of the pore spaces within the soil thereby allowing for more affinity of water and hence absorption. Similar findings were reported by Abo-El-Enein et al. [2] and Osinubi et al. [24, 26].

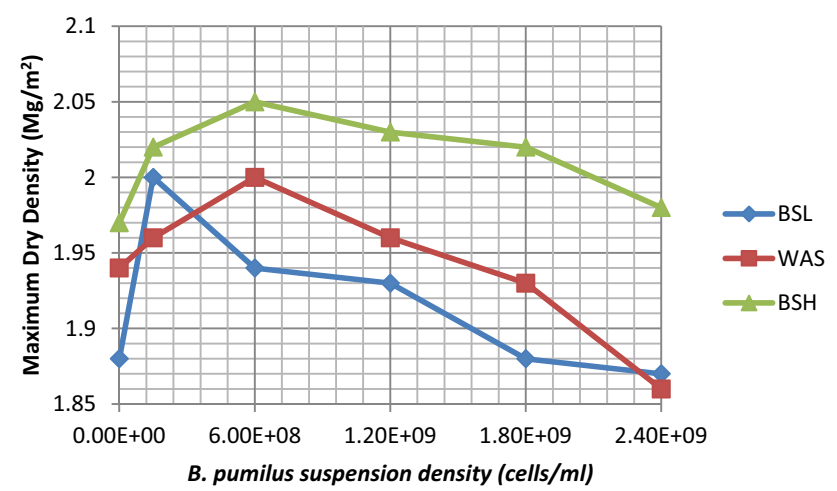

Fig. 5 Variation of the MDD of the lateritic soil with B. pumilus suspension density treatment at different compactive effort

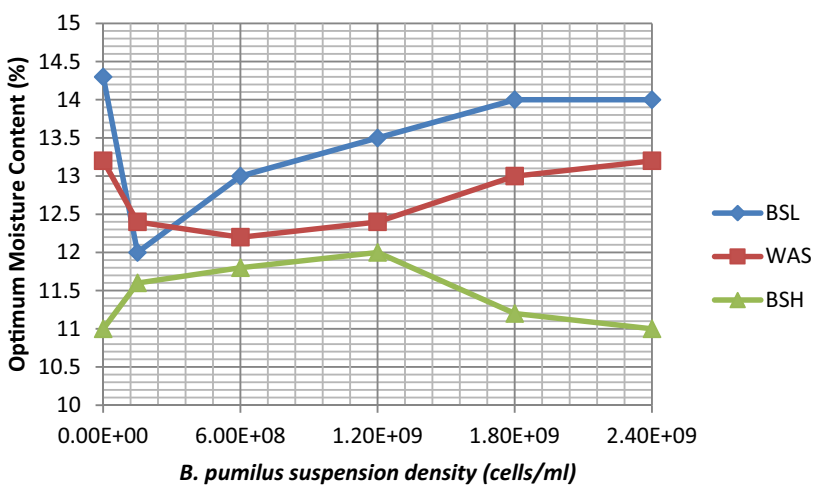

Fig. 6 Variation of the OMC of the lateritic soil with B. pumilus cells/ $\mathrm{ml}$ suspension density treatment at different compactive effort

\subsection{Calcite content test}

The variation of calcite content for lateritic soil mixed with stepped B. pumilus suspension density is shown in Fig. 7. After the MICP treatment for all densities of B. pumilus suspension, the sample was extruded from the mould to see the formation of calcite content across the treated sample. Generally, the calcite content of the lateritic soil initially increased with an increase in B. pumilus suspension density. It was also observed that a higher concentration of calcite was formed at $1.8 \times 10^{9}$ cells $/ \mathrm{ml}$. The picture of the calcite crystal formed as a result of the MICP process is shown in Fig. 8 which is whitish in colour and is responsible for the increase in resistivity of the soil.

\subsection{Electrical resistivity}

The variation of Resistivity with B. pumilus cells $/ \mathrm{ml}$ at different compactive effort considered and for 7 days curing is as shown in Fig. 9. The general trend of the resistivity shows a general increase with an increase in B. pumilus suspension density treatment for all compactive effort considered, and the highest resistivity values were obtained

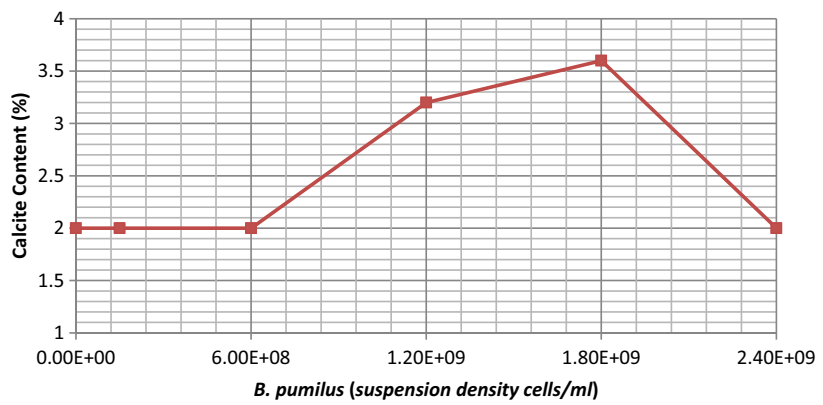

Fig. 7 Variation of calcite content of lateritic soil with B. pumilus suspension density cells/ml 
Fig. 8 Picture showing the calcite crystal formed as a result of the MICP process

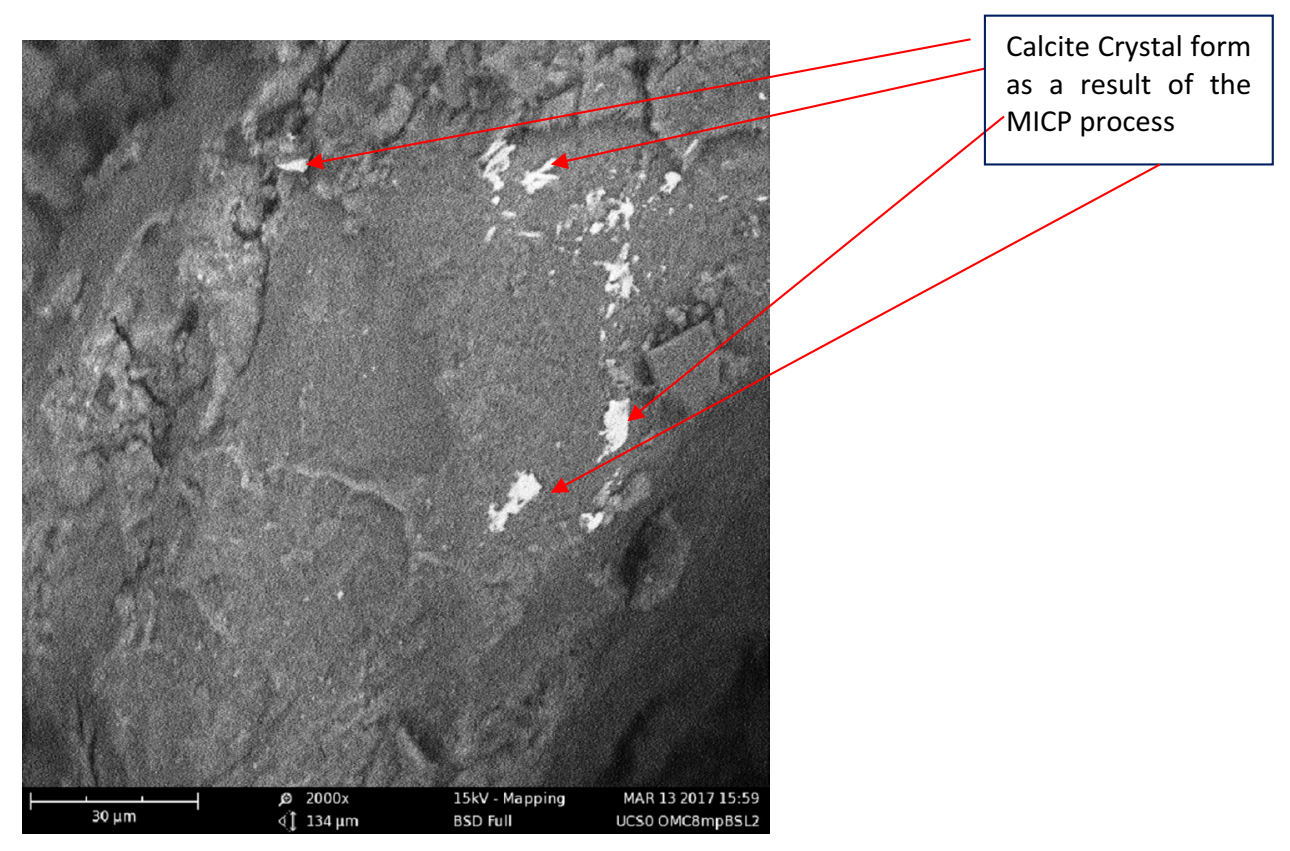

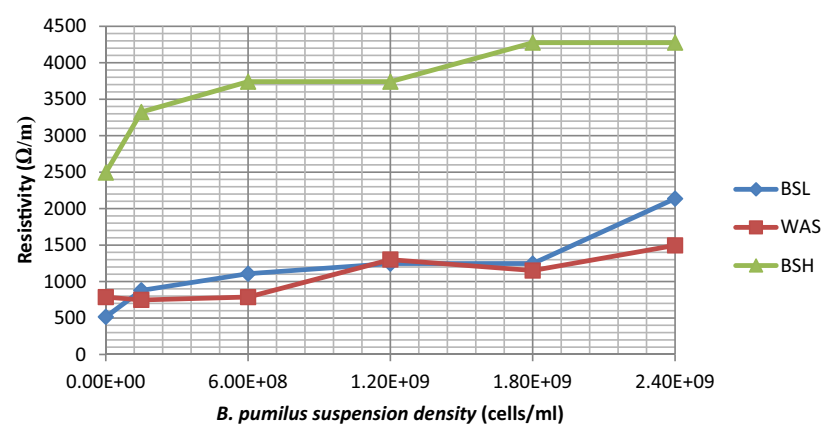

Fig. 9 Variation of the resistivity of the lateritic soil with B. pumilus cells/ml suspension density treatment at 7 days curing for different compactive effort

at BSH compactive effort. The result indicates that the resistivity value is a function of both compactive effort and bacteria density. It also indicates that calcites were formed through the MICP process. The resistivity value of the natural soil cured for 7 days increases from a value of $515.929(\Omega / \mathrm{m})$ to $2137.42(\Omega / \mathrm{m})$ at $2.4 \times 10^{9}$ cells $/ \mathrm{ml}$ of B. pumilus suspension density for BSL compactive effort, $787.47(\Omega / \mathrm{m})$ to $1496.19(\Omega / \mathrm{m})$ at $2.4 \times 10^{9}$ cells $/ \mathrm{ml}$ of $B$. pumilus suspension density for WAS compactive effort and $2493.657(\Omega / \mathrm{m})$ to $4274.841(\Omega / \mathrm{m})$ at $2.4 \times 10^{9}$ cells $/ \mathrm{ml}$ of $B$. pumilus suspension density for BSH compactive effort.

The variation of resistivity with B. pumilus cells $/ \mathrm{ml}$ at different compactive effort considered and for 28 days of curing is as shown in Fig. 10. The general trend of the resistivity shows a general increase with an increase in B. pumilus suspension density treatment for all compactive effort considered, and higher resistivity values were

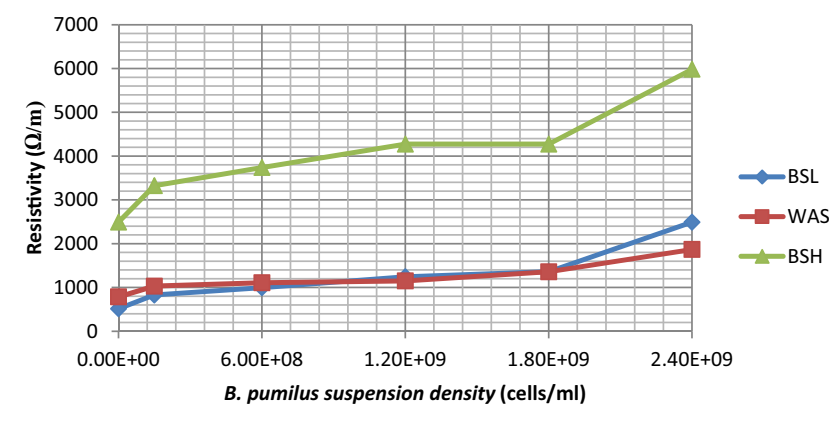

Fig. 10 Variation of the resistivity of the lateritic soil with B. pumilus cells $/ \mathrm{ml}$ suspension density treatment at 28 days curing for different compactive effort

obtained at BSH compactive effort while BSL and WAS compactive effort gave relatively same resistivity values. The samples were cured for 28 days to see the long-time effect of curing on the resistivity value. The resistivity value obtained for the 28 days curing were higher than those obtained for the 7 days curing. The result obtained also indicates that higher resistivity value is a function of compactive effort and also the calcites that were formed through the MICP process. The resistivity value of the natural soil cured for 28 days increased from a value of $515.929(\Omega / \mathrm{m})$ to $2493.66(\Omega / \mathrm{m})$ at $2.4 \times 10^{9} \mathrm{cells} / \mathrm{ml}$ of B. pumilus suspension density for BSL compactive effort, $787.47(\Omega / \mathrm{m})$ to $1870.24(\Omega / \mathrm{m})$ at $2.4 \times 10^{9}$ cells $/ \mathrm{ml}$ of $B$. pumilus suspension density for WAS compactive effort and $2493.657(\Omega / \mathrm{m})$ to $5984.776(\Omega / \mathrm{m})$ at $2.4 \times 10^{9}$ cells/ $\mathrm{ml}$ of $B$. pumilus suspension density for $\mathrm{BSH}$ compactive effort. 
To further test the long-time effect of curing on the resistivity value of $B$. pumilus suspension density treatment for the soil was cure for 56 days. The variation of resistivity with $B$. pumilus cells $/ \mathrm{ml}$ at different compactive effort considered cured for 56 days is shown in Fig. 11. The same trend obtained for 7 days and 28 days was recorded for 56 days curing. Beyond 28 days, there is only a marginal increase in resistivity value because there is little or no increase in resistivity value obtained. The enzyme urease triggered the MICP biochemical reaction by hydrolyzing urea and the ammonium $\left(\mathrm{NH}_{4}^{+}\right)$produced increased the $\mathrm{pH}$ and caused the bicarbonate $\left(\mathrm{HCO}_{3}{ }^{-}\right)$to precipitate with calcium ion $\left(\mathrm{Ca}^{2+}\right)$ from the calcium chloride supplied to form calcium calcite $\left(\mathrm{CaCO}_{3}\right)$. The calcite generated was responsible for binding soil particles and clogging the pores in the soil specimens. Bio-cementation is achieved when the calcite crystals precipitate on the surface or form bridges between the existing soil grains. These calcite crystals formed are responsible for the bond between the soil particles and forbid movement of its grains, and therefore improves the strength and stiffness properties of the soil

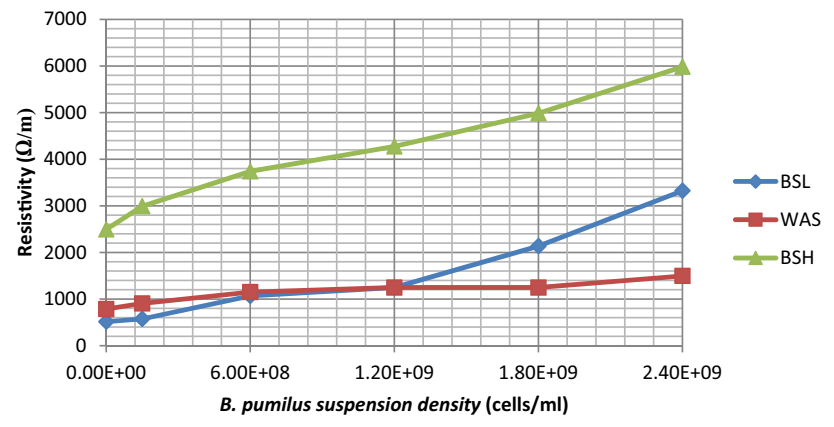

Fig. 11 Variation of the resistivity of the lateritic soil with B. pumilus cells $/ \mathrm{ml}$ suspension density treatment at 56 days curing for different compactive effort
$[13,21,27]$. At the end of the bio-cementation no further gain in strength which makes the resistivity at some point to be constant after long-time curing but there is no decrease in resistivity which shows that the treatment with MICP is sustainable for a long time period.

To access the effect of the curing period on the resistivity, Fig. 12 was plotted to compare the resistivity variation at different curing days for different compactive energy used. The results show that at BSL beyond 28 days curing there is a decrease in resistivity value except for treatment with $1.8 \times 10^{9}$ cells $/ \mathrm{ml}$ and $2.4 \times 10^{9}$ cells $/ \mathrm{ml}$ of $B$. pumilus suspension density. The result for the WAS compaction shows that there is no increase in resistivity values beyond 28 days and at most treatment a constant value was obtained with that of the 28 days curing except for $2.4 \times 10^{9}$ cells $/ \mathrm{ml}$ of $B$. pumilus suspension density that shows a slight decrease in the resistivity value. The results of the BSH compaction on the other hand show that beyond 28 days curing period the resistivity value remains constant for B. pumilus-treated soil for all suspension density except for $6.0 \times 10^{8}$ cells $/ \mathrm{ml}$ of $B$. pumilus suspension density that shows a slight decrease in resistivity value and $1.8 \times 10^{9}$ cells $/ \mathrm{ml}$ of $B$. pumilus suspension density that shows a slight increase in resistivity value.

\subsection{Relationship between resistivity and other properties considered}

The relationship between resistivity and specific gravity, liquid limit, plastic limit, plasticity index and linear shrinkage was determined using single regression of secondorder polynomial model, and the coefficient of determination $R^{2}$ is as shown in Figs. $13,14,15,16$ and 17. The coefficient of correlation $R$ is the square root of the coefficient of determination $R^{2}$.
Fig. 12 Variation of the resistivity of the lateritic soil with B. pumilus cells $/ \mathrm{ml}$ suspension density treatment at different curing days and different compactive effort

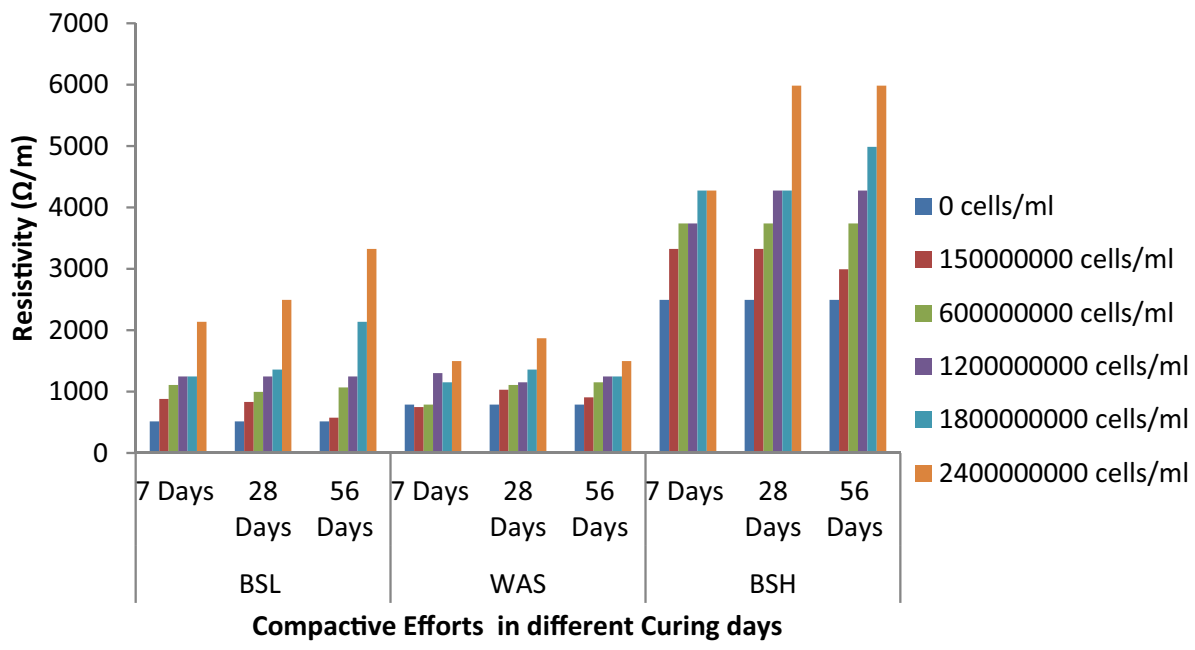

SN Applied Sciences 


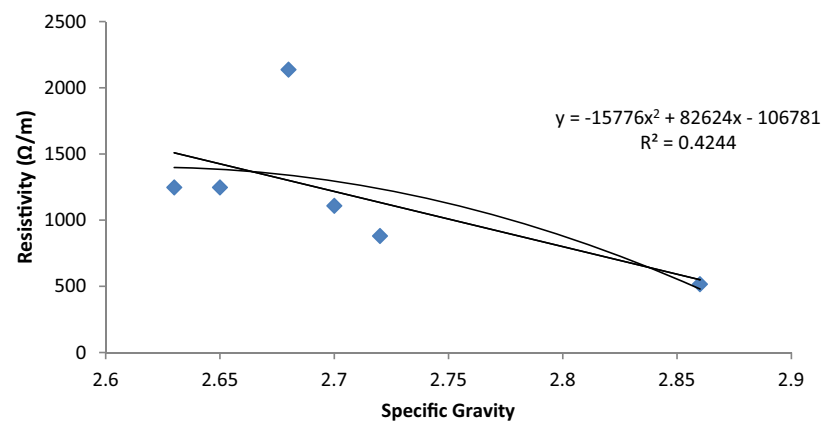

Fig. 13 Correlation of resistivity with specific gravity

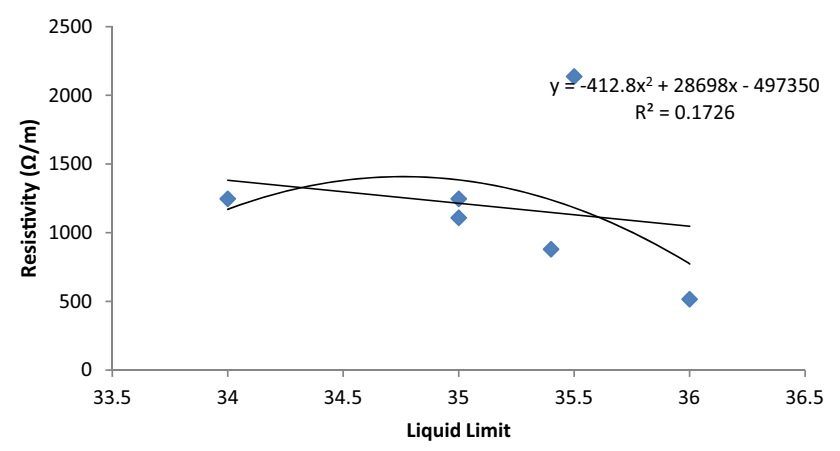

Fig. 14 Correlation of resistivity with liquid limit

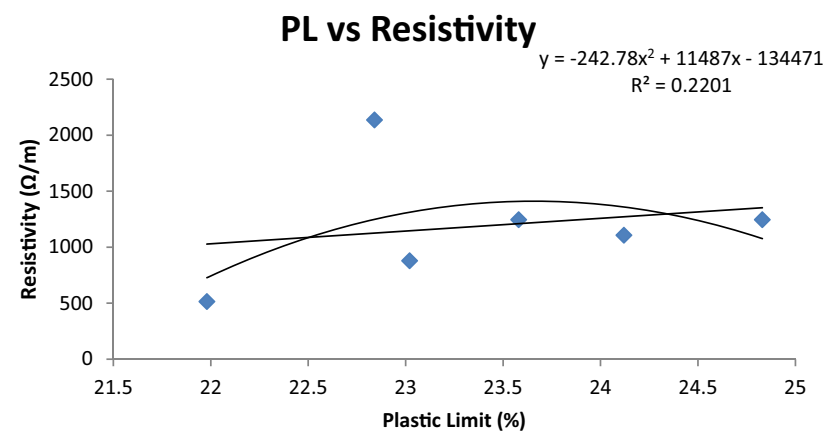

Fig. 15 Correlation of resistivity with plastic limit

The result shows that, generally, the relationship between the resistivity and all the parameters considered shows a decrease with an increase in those parameters except for the plasticity limit. The graph shows that the relationship between resistivity and specific gravity gave a coefficient of determination $R^{2}=0.424$ which is equivalent to the coefficient of correlation $R=0.651$. The relationship between resistivity and liquid limit gave a coefficient of determination $R^{2}=0.172$ which is equivalent to the coefficient of correlation $R=0.415$. The relationship between resistivity and plastic limit gave a coefficient of
PI vs Resistivity

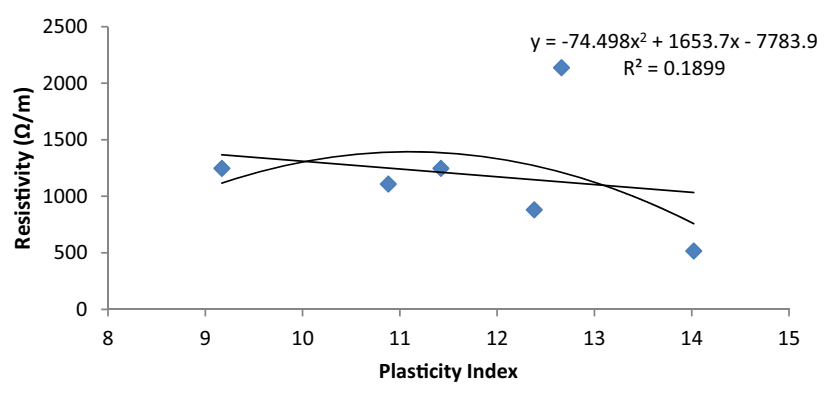

Fig. 16 Correlation of resistivity with plasticity index

\section{LS vs Resistivity}

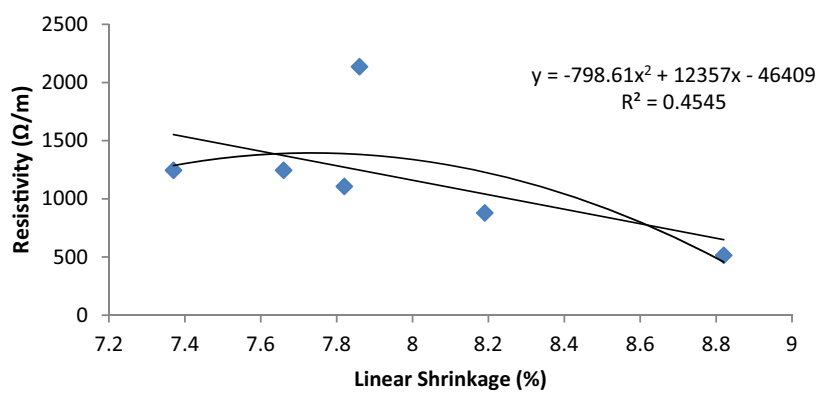

Fig. 17 Correlation of resistivity with linear shrinkage

determination $R^{2}=0.220$ which is equivalent to the coefficient of correlation $R=0.469$. The relationship between resistivity and plasticity index gave a coefficient of determination $R^{2}=0.189$ which is equivalent to the coefficient of correlation $R=0.435$. The relationship between resistivity and linear shrinkage gave a coefficient of determination $R^{2}=0.454$ which is equivalent to the coefficient of correlation $R=0.674$.

The results show that resistivity has more correlation with the linear shrinkage of the soil with $R=0.674$ followed by the specific gravity of the soil with $R=0.651$. The resistivity has a weak correlation with plastic limit, plasticity index and liquid limit with an $R$ value less than 0.5 .

\section{Conclusion}

Based on the results of the study on evaluating the electrical resistivity of $B$. pumilus microbial-induced calcite precipitate-treated lateritic soil at different compactive effort, it can be concluded that:

1. The specific gravity of the soil decreases with an increase in $B$. pumilus suspension density 
2. The Atterberg limits test shows that liquid limit, plasticity index and linear shrinkage decrease with an increase in B. pumilus suspension density to a minimum value of $34 \%, 9.17 \%$ and $7.27 \%$, respectively, at $1.2 \times 10^{9}$ cells $/ \mathrm{ml}$ of $B$. Pumilus suspension density. The plastic limit on the other hand increases with an increase in $B$. pumilus suspension density to a maximum value of 24.83 at $1.2 \times 10^{9}$ cells $/ \mathrm{ml}$ of $B$. pumilus suspension density.

3. The compaction characteristic shows that the maximum dry density decreases with an increase in $B$. pumilus suspension density after an initial increase but higher MDDs were recorded at BSH compaction energy. The optimum moisture content OMC, on the other hand, increases with increase in B. pumilus suspension density after an initial decrease except the sample compacted with BSH that reduces after $1.2 \times 10^{9}$ cells $/ \mathrm{ml}$ of $B$. pumilus suspension density. BSL compaction gave a higher OMC while BSH compaction gave lower OMC values.

4. The resistivity test result shows an increase in resistivity value with an increase in B. pumilus suspension density and also with an increase in compactive energy. Though there is a marginal increase between resistivity values of BSL compactive effort and that of WAS compactive effort.

5. The resistivity values obtained also show that resistivity values increase with curing days, i.e. the values increase between 7 days curing and 28 days curing but beyond 28 days curing period no significant increase in resistivity value.

6. The resistivity result also shows that long-time curing does not reduce the resistivity value which indicates that the MICP process can sustain the resistivity of the treated soil through the lifetime of the structural foundation.

7. The statistical analysis using correlation shows that resistivity has a good relationship with linear shrinkage and specific gravity of the soil with $R$ values above 0.65 .

8. The peak resistivity values were obtained at $2.4 \times 10^{9}$ cells $/ \mathrm{ml}$ of $B$. pumilus suspension density for all compactive effort considered.

Acknowledgements The authors gratefully acknowledge the immense support received from the Department of Civil Engineering, Nigerian Defence Academy (NDA) Kaduna, Nigeria for providing their Geotechnical Laboratory where the experimental works of this research were conducted and also thanks the Department of Microbiology Ahmadu Bello University for providing their Laboratory where the micro-organism was identified and cultured to produce the Bacillus pumilus suspension density and the cementitious reagent needed for the research.
Funding This research was sponsored by Tertiary Education Trust Fund (TETFUND) under the year 2015 TETFUND RESEARCH PROJECTS (RP) INTERVENTION: RELEASE OF FUND 15TH BATCH with reference TETFUND/DRSS/NDA/KADUNA/2014/RP/VOL. 1 Dated 14th March 2019.

\section{Compliance with ethical standards}

Conflict of interest The first author has received research grant from Tertiary Education Trust Fund (TETFUND). The second author did not receive any grant from any company and the third author also did not receive any grant from any company. No conflict of interest for second and third authors.

\section{References}

1. AASHTO (1986) Standard specifications for transport materials and methods of sampling and testing, 14th edn. American Association of State Highway and Transport Officials (AASHTO), Washington, DC

2. Abo-El-Enein SA, Ali AH, Talkhan FN, Abdel-Gawwad HA (2012) Utilization of microbial induced calcite precipitation for sand consolidation and mortar crack remediation. J Hous Build Natl Res Cente 8:185-192

3. ASTM (1992) Annual book of standards, vol 04.08. American Society for Testing and Materials, Philadelphia

4. Burbank M, Weaver T, Green T, Williams B, Crawford R (2011) Precipitation of calcite by indigenous microorganisms to strengthen liquefiable soil. Geomicrobiol J 28(4):301-312

5. BS 1377 (1990) Methods of testing soils for civil engineering purposes. British Standard Institution, London

6. Choi SG, Chu J, Park SS, Wu S, Chu J (2017) Method for calcium content measurement of biocemented soils. J Mater Civ Eng 29(11):1-4

7. DeJong JT, Fritzges MB, Nüsslein K (2006) Microbially induced cementation to control sand response to undrined shear. J Geotech Geoenviron Eng 132:1381-1392

8. DeJong JT, Martinez BC, Mortensen BM, Nelson DC, Waller JT, Weil MH, Ginn TR, Weathers T, Barkouki T, Fujita Y, Redden G, Hunt C, Major D, Tanyu B (2009) Upscaling of bio-mediated soil improvement. In: Proceedings of the 17th International Conference on. Soil Mechanics and Geotechnical Engineering, Alexandria, pp 2300-2303

9. Dejong JT, Soga KS, Kavazanijian E, Burns S, Van Paassen L, Al Qabany A, Aydilek A, Bang SS, Burbank M, Caslake L, Chen CY, Cheng X, Chu J, Ciurli S, Fauriel S, Filet AE, Hamdan N, Hata T, Inagaki Y, Jefferis $S$, Kuo M, Laloui L, Larrahondo J, Manning DAC, Martinez B, Montoya BM, Nelson DC, Palomino A, Renforth P, Santamarina JC, Seagren EA, Tanyu B, Tsesarsky M, Weaver T (2013) Biogeochemical processes and geotechnical applications: progress, opportunities and challenges. Geotechnique 63(4):287-301. https://doi.org/10.1680/geot.SIP13.P.017

10. Frempong EM, Yanful EK (2008) Interactions between three tropical soils and municipal solid waste landfill leachate. J Geotech Geoenviron Eng ASCE 134(3):379-396

11. Gao Y, Hang L, He J, Chu J (2018) Mechanical behaviour of biocemented sands at various treatment levels and relative densities. Acta Geotech. https://doi.org/10.1007/s11440-018-0729-3

12. Goswami RK, Mahanta C (2007) Leaching characteristics of residual lateritic soils stabilized with fly ash and lime for geotechnical applications. Waste Manag 27(4):466-481

13. Harkes MP, Van Paassen LA, Booster JL, Whiffin VS, Van Loosdrecht MCM (2010) Fixation and distribution of bacterial 
activity in sand to induce carbonate precipitation for ground reinforcement. Ecol Eng 36(2):112-117

14. Inagaki $Y$, Tsukamoto $M$, Mori $H$, Sasaki T, Soga $K, A$ I Qabany A, Hata $T$ (2011) The influence of injection conditions and soil types on soil improvement by microbial functions. In: Proceedings of GeoFrontiers 2011: advances in geotechnical engineering, Dallas, TX, ASCE geotechnical special publication 211, pp 4021-4030

15. Ivanov V, Chu J (2008) Applications of microorganisms to geotechnical engineering for bioclogging and biocementation of soil in situ. Rev Environ Sci Biotechnol 7:139-153

16. Joachin AWR, Kandiah S (1941) The composition of some local laterites, soil concretions and clays. Trop Agric 96:67-75

17. McFarland J (1907) Nephelometer: an instrument for media used for estimating the number of bacteria in suspensions used for calculating the opsonic index and for vaccines. J Am Med Assoc 14:1176-1178

18. Mahawish A, Bouazza A, Gates WP (2019) Factors affecting the bio-cementing process of coarse sand. Ground Improv 172(1):25-36. https://doi.org/10.1680/jgrim.17.00039

19. Martinez BC, DeJong JT (2009) Bio-mediated soil improvement: load transfer mechanisms at micro- and macro-scales. In: Proceedings of 2009 ASCE US-China workshop on ground improvement technologies, Orlando, FL, pp 242-251

20. Martinez BC, DeJong JT, Ginn TR, Mortensen BM, Barkouki TH, Hunt C, Tanyu B, Major D (2013) Experimental optimization of microbial induced carbonate precipitation for soil improvement. ASCE J Geotech Geoenviron Eng (in press)

21. Mujah D, Shahin MA, Cheng L (2017) State-of-the-art review of biocementation by microbially induced calcite precipitation (MICP) for soil stabilization. Geomicrobiol J 34(6):524-537. https://doi.org/10.1080/01490451.2016.1225866

22. Mostafa M, Anwar MB, Radwan A (2018) Application of electrical resistivity measurement as quality control test for calcareous soil, vol 14. Housing and Building National Research Center. Production and Hosting by Elsevier, Amsterdam, pp 379-384. https://doi.org/10.1016/j.hbrcj.2017.07.001

23. Osinubi KJ, Amadi AA, Eberemu AO (2009) Diffusion of municipal waste contaminants in compacted lateritic soil treated with bentonite. In: 10th International symposium on environmental geotechnology and sustainable development (TFHISEGSD Bochum 2009), Bochum, Germany, 7-11 September, Ed. Otto, Frank. Science Publishers, Stuttgart, pp 102-106

24. Osinubi KJ, Eberemu AO, Ijimdiya ST, Yakubu SE, Sani JE (2017) Potential use of Bacillus Pumilus in microbial induced calcite precipitation improvement of lateritic soil. In: Proceedings of the 2 nd symposium on coupled phenomena in environmental geotechnics (CPEG2), Leeds, United Kingdom, 6-8 September. Session: Clean-ups, Paper \#64, pp 1-6

25. Osinubi KJ, Nwaiwu CMO (2008) Desiccation induced shrinkage in compacted lateritic soil J Geotech Geol Eng 1513-1529. ISSN 0960-3182 (Print)

26. Osinubi KJ, Eberemu AO, Sani JE, Ijimdiya TS, Taman J, Abdulmutallib M (2018) Effect of Bacillus pumilus-induced precipitation on the index properties and compaction characteristics of lateritic and black cotton soils. In: 2018 Nigerian Building and Road Research Institute international conference. Theme: Sustainable Development Goals (SDGs) and the Nigerian Construction Industry - challenges and the way forward, 12-14 June, Abuja, Nigeria, Book of Abstracts, p 41

27. Osinubi KJ, Sani JE, Eberemu AO, Ijimdiya TS, Yakubu SE(2019) Unconfined compressive strength of Bacillus pumilus treated lateritic soil. In: Zhan L, Chen Y, Bouazza A (eds) Proceedings of the 8th international congress on environmental geotechnics (ICEG 2018), towards a sustainable geoenvironment, 28th October-1st November, Hangzhou,
China, vol 3. Springer, Singapore, pp 410-418. https://doi. org/10.1007/978-981-13-2227-3_51

28. Osinubi KJ, Eberemu AO, Gadzama EW, Ijimdiya TS (2019) Plasticity characteristics of lateritic soil treated with Sporosarcina pasteurii in microbial-induced calcite precipitation application. SN Appl Sci 1:829. https://doi.org/10.1007/s4245 2-019-0868-7

29. Osinubi KJ, Yohanna P, Eberemu AO, Ijimdiya TS (2019) Evaluation of hydraulic conductivity of lateritic soil treated with Bacillus coagulans for use in waste containment applications. In: Zhan L, Chen Y, Bouazza A (eds) Proceedings of the 8th international congress on environmental geotechnics (ICEG 2018). Towards a sustainable geoenvironment, vol 3. Springer, Hangzhou, pp 401-409. https://doi. org/10.1007/978-981-13-2227-3_50

30. Osinubi KJ, Sani JE, Eberemu AO, Ijimdiya TS, Yakubu SE (2019) Unconfined compressive strength of Bacillus pumilus treated lateritic soil. In: Zhan L, Chen Y, Bouazza A (eds) Proceedings of the 8th international congress on environmental geotechnics (ICEG 2018). Towards a sustainable geoenvironment, vol 3. Springer, Hangzhou, pp 410-418. https://doi. org/10.1007/978-981-13-2227-3_51

31. Osinubi KJ, Gadzama EW, Eberemu AO, Ijimdiya TS, Yakubu SE (2019) Evaluation of the strength of compacted lateritic soil treated with Sporosarcina pasteurii. In: Zhan L, Chen Y, Bouazza A (eds) Proceedings of the 8th international congress on environmental geotechnics (ICEG 2018). Towards a sustainable geoenvironment, vol 3. Springer, Hangzhou, pp 419-428. https://doi.org/10.1007/978-981-13-2227-3_52

32. Osinubi KJ, Eberemu AO, Ijimdiya TS, Yakubu SE, Gadzama EW, Sani JE, Yohanna P (2020) Review of the use of microorganisms in geotechnical engineering applications. SN Appl Sci 2:207. https://doi.org/10.1007/s42452-020-1974-2

33. Portelinha FHM, Lima DC, Fontes MPF, Carvalho CAB (2012) Modification of a lateritic soil with lime and cement: an economical alternative for flexible pavement layers. Soils Rocks São Paulo 35:51-63

34. Qabany AA, Mortensen B, Martinez B, Soga K, Dejong J (2011) Microbial carbonate precipitation correlation of s-wave velocity with calcite precipitation. Geo-Frontiers 2011:3993-4001

35. Salahedin M (2013) Effects of CEC on Atterberg limits and plastic index in different soil textures. Int J Agron Plant Prod 4(9):2111-2118

36. Stocks-Fischer S, Galinat JK, Bang SS (1999) Microbiological precipitation of $\mathrm{CaCO}_{3}$. Soil Biol Biochem 31(11):1563-1571

37. Stoner DL, Watson SM, Stedtfeld RD, Meakin P, Griffel LK, Tyler TL, Pegram LM, Barnes JM, Deason VA (2005) Application of stereo lithographic custom models for studying the impact of biofilms and mineral precipitation on fluid flow. Appl Environ Microbiol 71(12):8721-8728

38. Tobler DJ, Maclachlan E, Phoenix VR (2012) Microbially mediated plugging of porous media and the impact of different injection strategies. Ecol Eng 42:270-278

39. Townsend FC (1985) Geotechnical characteristics of residual soils. J Geotech Eng Div ASCE 111(1):77-94

40. Van Paassen LA (2009) Biogrout, ground improvement by microbially induced carbonate precipitation. Doctoral dissertation, Department of Biotechnology, Delft University of Technology, the Netherlands

41. van Paassen LA (2011) Bio-mediated ground improvement: from laboratory experiment to pilot applications. In: Proceedings of geofrontiers in geotechnical engineering 2011: technical papers, ASCE, pp 4099-4108

42. Van Paassen LA, Harkes MP, Van Zwieten GA, Van der Zon WH, Van der Star WRL, Van Loosdrecht MCM (2009) Scale up of BioGrout: a biological ground reinforcement method. In: 17th 
international conference on soil mechanics and geotechnical engineering, Alexandria, pp 2328-2333

43. Vincent NA, Shivashankar R, Lokesh KN (2017) Laboratory and field electrical resistivity studies on laterite and lateritic soil. Electron J Geotech Eng (EJGE) 22(07):2637-2664
Publisher's Note Springer Nature remains neutral with regard to jurisdictional claims in published maps and institutional affiliations.

\section{SN Applied Sciences}

a SPRINGer NATURE journal 